\title{
CYP26B1 Gene
}

National Cancer Institute

\section{Source}

National Cancer Institute. CYP26B1 Gene. NCI Thesaurus. Code C104874.

This gene plays a role in the metabolism of retinoic acid. 